PROBLEMS

OF EDUCATION IN THE $21^{\text {st }}$ CENTURY Vol. 78, No. 6,2020

920

\title{
PERCEPTIONS OF TODAY'S YOUNG GENERATION ABOUT MEANINGFUL LEARNING OF STEM
}

\author{
Dagnija Cedere, Rita Birzina, Tamara Pigozne \\ University of Latvia, Latvia \\ E-mail: dagnija.cedere@lu.Iv, rita.birzina@lu.Iv, tamara.pigozne@lu.Iv \\ Elena Vasilevskaya \\ Belarusian State University, Republic of Belarus \\ E-mail: vasileli@bsu.by
}

\begin{abstract}
The necessity of STEM knowledge is being more widely acknowledged as the priority in the development of education; however, students lack sufficient knowledge and interest in the acquisition of STEM subjects. Therefore, more attention should be paid to the teaching and learning methods that would correspond to the contemporary young generation and that would facilitate meaningful learning of modern students. Performing the survey of 256 students in Grades 10 - 12 of Latvia, students' perceptions on how they understand and interpret their STEM learning and methods used by teachers have been explored. The questionnaire in the QuestionPro e-environment was designed according to the criteria describing meaningful learning considering the peculiarities of the young generation. Respondents' answers were analyzed with the help of the SPSS program, using the methods of non-parametric statistics. Many representatives of the young generation tend to avoid difficulties which confirms a typical feature of this generation - to achieve an immediate result easily and quickly. These students also have a weaker understanding about the importance of STEM that testifies the lack of the learning motivation. The majority of students consider that it is necessary to acquire STEM only at school, failing to connect it with the everyday life. The study describes the national context, yet the presented trends could be significant also on the international level for understanding meaningful learning of STEM.
\end{abstract}

Keywords: meaningful learning, STEM education, teaching/learning methods, today's new generation

\section{Introduction}

A person needs qualitative education to be able to realize oneself successfully in the rapidly changing world of the future. It is the knowledge system that takes shape by adjusting to new kinds of actions and means of communication being in a continuous self-development. One of the most important and at the same time most complicated cornerstones in the $21^{\text {st }}$ century education is STEM (Science, Technology, Engineering and Mathematics) (Berk, 2009; Chin \& Osborne, 2008).

When generations change, one has to be aware that each generation not only has its own opinions but also its own values, motivation and attitude. Although there does not exist strict, common opinion about the division of generations and criteria that define it, usually the duration allotted to each generation lasts from fifteen to twenty years (Moore et al., 2017). According to the generational theory also known as the Fourth Turning theory (Howe \& Strauss, 1997), all students of today belong to the Generation $Y$ and Generation Z (Generation Y, 1984-1999 year of birth and Generation Next or Z, 2000 - ...... year of birth). Generation Y 
is also known as Millennial generation. There are still discussions whether it is possible to draw a border between the Millennials and Generation Z. Both generations have much in common, especially regarding the use of technology (computers, smart phones, and the Internet). Prensky (2001) introduced the term "Digital Natives" to describe the representatives of the Millennium generation. However, Generation $\mathrm{Z}$ members have been especially influenced by immersion in technology since birth. Today's students who belong to Generation Z use the digital environment on everyday basis - social media, the services of immediate news exchange, social networks; they use applications in their mobile gadgets that are continuously available. A great part of students' life happens and develops in the digital environment. "Digital Natives" think and learn fundamentally differently owing to their experience in the digital world (Moore et al., 2017). The $21^{\text {st }}$ century is considered to be the beginning of the digital age - the age with unprecedented advance of the progress of technologies and information explosion following it. Although the Millennium and $\mathrm{Z}$ generations at present are ascribed to various differences in opinions and behavior, yet the most important is the fact that today's new generation, their thinking and learning style are strongly affected by technologies and the strength of this impact is ever growing (Kirschner \& De Bruyckere, 2017; Seemiller \& Grace, 2017).

The current educational context requires the transition from the dominant positive behaviorism model that gives preference to mechanic learning and to cognitively constructivist that would stimulate meaningful learning. This new paradigm allows students to construe knowledge becoming creative and critically thinking citizens where students play an active role not only learning about the product but through the process itself (metacognition). Learners' knowledge construction and reconstruction of meanings requires that they should actively integrate new knowledge with existing knowledge (González et al., 2001; Novak, 2002).Worldwide economic changes are forcing major changes in business and industry placing a premium on the power and value of knowledge and new knowledge production. The necessity to develop students' higher order thinking skills becomes more and more topical (Darling-Hammond, 2020).

\section{Research Problem}

Education process has to change under the impact of the rapid spread of information technologies. The internationally acknowledged skills necessary for life in the $21^{\text {st }}$ century include creativity and innovation, critical thinking and problem solving, communication, collaboration, information management, effective use of technology, career and life skills, and cultural awareness that are closely connected with the learning peculiarities of today's new generation. STEM domain is extremely intrinsic for the acquisition of the above-mentioned skills. It is necessary to find new approaches, to seek an individual approach to every student according to his or her needs in the teaching/learning process (Beers, 2011, Sharples et al., 2016) to make the acquisition of STEM meaningful at school.

Meaningful acquisition of science and mathematics means not only connecting the content knowledge of learning with the real life examples and problem situations but also deep understanding of learning by focusing on projects and problems. Meaningful learning helps students to understand and develops their thinking. The use of technologies gives students an opportunity to access, analyze, organize and share the information to be acquired with others, choosing independently applications that are the most appropriate for them. Thus, the student functions not only in a reproductive way as the consumer of information but also becomes productive - the creator of knowledge (Beers

The knowledge of the STEM subject domain rests on the understanding of nature phenomena/processes, evidence, data and observations. This means that a student has to perform practical experiments, has to be able to evaluate and interpret the obtained data and be 
Dagnija CEDERE, Rita BIRZINA, Tamara PIGOZNE, Elena VASILEVSKAYA. Perceptions of today's young generation about meaningful learning of STEMlearning of STEM

PROBLEMS

OF EDUCATION IN THE $21^{\text {st }}$ CENTURY Vol. 78, No. 6, 2020

922

able to draw conclusions (Lederman et al., 2002). The acquisition of science in the laboratory is connected not only with the argumentation and formation of scientific substantiation of statements but also students' attitude, conditions of effective learning, students' ideas about the teaching/learning environment, social interaction and differences in learning styles and cognitive abilities (Hofstein \& Lunetta, 2004).

At present, there are contradictions between the years' old customary approach of teaching science and the new education development trends, the expansively developing digital environment and schools' infrastructure, the student who has adjusted to the digital environment and the teacher who has to manage to adapt to these changes. Thus, when organizing the teaching/learning process the teacher should adjust to the needs of the new generation and in the acquisition of STEM the teacher should concentrate on the development of higher order thinking applying technologies in the context of the teaching/learning process, e-communication and collaboration.

As confirmed by previously performed studies, students' interest in STEM is low which, in turn, causes the decrease in the level of knowledge (Potvin \& Hasni, 2014). Studies show that first year students in higher education institutions encounter difficulties with science subjects and mathematics because they do not have sufficient preliminary knowledge in these subjects (Birzina \& Cedere, 2017; Birzina et al., 2019). Learning of science and mathematics presents serious difficulties to the majority of today's students, thus the level of their knowledge decreases (Mahmoud, 2018; Playfoot, 2017). It is possible that insufficiency of knowledge is determined by the fact that the teaching/learning process fails to use real life examples and hands-on experience (Fadzil et al., 2019; Tsaparlis, 2020). However, in literature there are few broader studies on the connection between students' perception about STEM and the peculiarities of them as the contemporary young generation.

\section{Research Focus}

Modern students are open to changes; they adjust quickly to them and are oriented to themselves and their needs (Rubene, 2018). Differently from the previous generation, they do not like the feeling of "being taught" and they try to learn to be the master of the situation therefore it is advisable to ensure the teaching/learning environment that would stimulate selfdirected, self-managed learning. This means that a teacher has to focus on the individualized teaching/learning process. The new generation prefers a more inclusive environment therefore they need to be ensured by strong peer learning and group work. They are focused on acquiring practical skills that are needed for the concrete situation and life, therefore the STEM acquisition has to include practical activities that are connected with the solution of real life situations (Howell et al., 2009). In order to ensure student appropriate learning, the process should include diverse learning strategies, suitable technologies, project- and problem-based learning, the integration of interdisciplinary topics, enquiry-based and practical cognitive activities, students' collaboration, high levels of visualization and the use of visuals to increase the understanding and giving immediate feedback, including the student's self-assessment. The teacher's role in the $21^{\text {st }}$ century classroom changes from the knowledge provider, an "expert" to the learning "facilitator", and the teaching/learning approach shifts from "knowing" to being able to use and apply information in relevant ways (Beers, 2011).

The most important of all the elements of the teaching/learning process are planning (programming), implementation (activities) and assessment (the acquisition of skills or competencies). It is exactly the assessment, using such methods as Portfolio and incubator (Pollard, 2018), that in this new education scenario has the key role in promoting continuous improvements and eliminating the shortcomings (Godino et al., 2013).

The new generation prefers an inclusive environment - the orientation to teamwork and 
collaboration is the desired teaching/learning environment of today's students that ensures strong peer learning. They see their success in group dynamics because independent work is connected with greater risk of personal failure giving preference to collaboration in projects, in solving practical situations, in exploring cases, to simulations in role plays using multimedia and social learning platforms (Seemiller \& Grace, 2017; Swanzen, 2018). However,) maintain that modern new generation prefers working alone and they sometimes lack creativity. These students more willingly seek precise references and examples to follow and at the same time they consider themselves to be thinking, open and responsible persons. A clear and concrete aim that shows the sense for self-development thus building the motivation for learning is important for today's students (Nel, 2017). The possibility to use their own digital gadgets in the learning process which ensures the access to learning tools and materials that they consider the most appropriate for fulfilling their personal learning needs necessary for gaining a meaningful and binding learning experience, corresponds to their needs and interests (Rosen, 2010; Tapscott, 2009).

The peculiarities of each new generation present challenges to teachers' professionalism. The studies performed in Latvia have a philosophical perspective and they are more related to the social environment than the teaching/learning process (Rubene, 2018). The organization of the STEM teaching/learning process and methods in relation with the peculiarities of the new generation have been little studied in Latvia. The question to what extent the school today ensures the STEM teaching/learning process according to the peculiarities and needs of the new generation and whether the teaching strategies and methods are effective, and learning is meaningful is still open. The performed study on students' opinion puts forward the following research questions:

- How do students perceive STEM learning at school?

- How does the STEM teaching/learning process correspond to the peculiarities of the modern new generation?

\section{Research Methodology}

\section{General Background}

The problems that exist in the acquisition of STEM are connected with the teaching/ learning in which the gap develops between the ideally organized meaningful learning and students' learning that takes place in reality. In order to explore it, the study looks at students' perception of STEM learning from the point of view of their personal gains as well as the aspects of the awareness of learning difficulties, the use of teaching/learning methods and strategies, the use of technologies, collaboration, communication and receiving the feedback.

A study is based on students' survey that describes the learning of STEM at school. Students' answers are analyzed in the context of intergenerational change in relation to peculiarities of the contemporary young generation. Grade 10 - 12 students from Latvian schools participated in the survey. Continuing the previous study (Cedere et al., 2019), students' perceptions and learning habits have been interpreted more profoundly. Respondents' answers have been analyzed with the SPSS program, applying the methods of non-parametric statistics. The study was conducted in 2017.

\section{Sample}

The participants of the study were Grade 10 - 12 students from general comprehensive schools, including secondary schools and gymnasia, of Latvia that learn according to the common Latvian National curriculum (mathematics from Grade 1 and biology, physics and

\begin{tabular}{|l} 
PROBLEMS \\
OF EDUCATION \\
IN THE 21 $1^{\text {st }}$ CENTURY \\
Vol. 78, No. 6, 2020 \\
\hline 923
\end{tabular} 
Dagnija CEDERE, Rita BIRZINA, Tamara PIGOZNE, Elena VASILEVSKAYA. Perceptions of today's young generation about meaningful learning of STEM

PROBLEMS

OF EDUCATION IN THE $21^{\text {st }}$ CENTURY Vol. 78, No. 6, 2020

chemistry from Grade 7 or 8). There can be a greater number of lessons in some of the subjects of the STEM domain in gymnasia (differing from secondary schools) which depends on the respective profile of the school or class. The school profile was not considered in the study. Schools involved in the study represent all regions of Latvia.

256 students from secondary schools and gymnasia of Latvia learning in Grade 10 ( $\mathrm{n}=96$; $37 \%), 11(\mathrm{n}=112 ; 44 \%)$ and $12(\mathrm{n}=48 ; 19 \%)$ participated in the study. Of the total number of respondents $161(63 \%)$ are female and $95(37 \%)$ male students. The average age of respondents is 17.3 years. The sample is appropriate to describe the general trends and problems in the teaching/learning process of STEM.

\section{Instrument and Procedures}

The questionnaire of the survey is designed based on the research ideas of authors from different countries (Berk, 2009; Chin \& Osborne, 2008; DiLullo, 2015; Grabinger \& Dunlap, 1995; Hofstein \& Lunetta, 2004; Lederman et al., 2002) and the previous studies of the article's authors about learning of STEM at school (Cedere et al., 2018; Birzina et al., 2019).

The questionnaire is designed taking into account two aspects - characteristic features of a meaningful STEM teaching/learning process and learning peculiarities of today's young generation by employing closed-open questions using 5-point Likert scale (from 1-strongly disagree to 5 -strongly agree). The reliability of the questionnaire according to Cronbach's alpha coefficient was 0.94 .

Students participated in the survey on the voluntary principle; they filled in the questionnaire in the online platform of QuestionPro. Teachers of the involved schools helped to organize the survey acting as mediators and sending their students the link to the electronic questionnaire.

According to the theoretical basis of the research, six criteria characterizing students' learning and indicators that correspond to these criteria have been defined (Table 1). 43 questions of the questionnaire were used in the data analysis.

\section{Table 1}

Criteria and Indicators Characterizing Meaningful STEM Learning According to Learning Peculiarities of Today's New Generation

\begin{tabular}{lll}
\hline Code & Criteria & Indicators \\
\hline C1 & Personal benefits & Interest and motivation. Knowledge and skills. Usefulness in a real life situation. \\
\hline C2 & $\begin{array}{l}\text { Learning methods and } \\
\text { strategies }\end{array}$ & $\begin{array}{l}\text { Active learning. Projects. Formation of argumentation skills. Experimental and } \\
\text { practical works. Visualization. Problem solving. Creativity. }\end{array}$ \\
\hline C3 & $\begin{array}{l}\text { Collaboration and } \\
\text { communication }\end{array}$ & $\begin{array}{l}\text { Expressing personal opinion and listening to others' opinions. Discussions. Team } \\
\text { work. Collaboration in project work. }\end{array}$ \\
\hline C4 & Use of technologies & $\begin{array}{l}\text { E-class. Searching for information in the internet. Use of Microsoft Office } \\
\text { applications. Use of the interactive board. Use of E-study materials. Chats, } \\
\text { forums and e-mail. Social networks. Video. }\end{array}$ \\
\hline C5 & Feedback & $\begin{array}{l}\text { Teacher's assessment. Self-assessment. Assessing the classmate. Receiving the } \\
\text { assessment from the classmate. }\end{array}$ \\
\hline C6 & Learning difficulties & Tests and taking them. Unwillingness to make an effort. \\
\hline
\end{tabular}


Dagnija CEDERE, Rita BIRZINA, Tamara PIGOZNE, Elena VASILEVSKAYA. Perceptions of today's young generation about meaningful learning of STEM

\section{Data Analysis}

The Cronbach's alpha test was used for internal consistency of the questionnaire. One sample Kolmogorov-Smirnov test helped to test that data followed a normal distribution. As the empirical data did not follow the normal distribution then Spearman's correlation analysis was used to determine the relations of the variables. The Kruskal-Wallis $H$ test was used to determine whether there were statistically significant differences between several groups of respondents. The Mann-Whitney $U$ test was used to compare differences between two groups of respondents.

\section{Research Results}

Having surveyed the students, the results gained from the questionnaires were first analyzed according to the criteria characterizing the new generation, then separate factors were looked upon in detail which revealed the most essential features of learning and allowed judging about the possibilities of further improvement of the teaching/learning process.

\section{Analysis of the Criteria of the STEM Teaching/Learning Process}

The Cronbach's alpha value .94 testifies to the good consistency of the questionnaire items in general. The Cronbach's alpha values calculated for describing the internal consistency of each separate criterion are presented in Table 2. Looking at the summarized data per criterion, one can see that respondents, in general, have different features characteristic to today's new generation. This is proved by the mean value $M$ of answers that according to all criteria on the 5- point scale is above " 3 " (Table 2). Criteria C1 - C5 indicate that teachers' methods and strategies of teaching and the teaching/learning environment in general are oriented to the young generation and students approve of the teaching/learning in STEM domain at school. However, the criterion C6 $(M=3.19 ; S D=0.98)$ proves that the majority of students are unwilling to make an effort when learning. Such a conclusion resulted also from the previously performed studies in Latvia. (Cèdere et al., 2018); thus, it is possible to consider that evasion from difficulties, the propensity to fast and easy result is a characteristic feature of today's students which greatly burdens the acquisition of the s. c. "hard" subjects - chemistry, physics and mathematics.

\section{Table 2}

Internal Consistency of Criteria and Their Mean Values $(N=256)$

\begin{tabular}{lllll}
\hline Criteria & Cronbach- $\boldsymbol{\alpha}$ & $\boldsymbol{M}$ & SD \\
\hline C1 & Personal benefits & .75 & 3.41 & 0.94 \\
\hline C2 & Learning methods and strategies & .82 & 3.48 & 0.89 \\
\hline C3 & Collaboration and communication & .73 & 3.39 & 0.88 \\
\hline C4 & Use of technologies & .68 & 3.26 & 1.10 \\
\hline C5 & Feedback & .73 & 3.20 & 0.94 \\
\hline C6 & Learning difficulties & .69 & 3.19 & 0.98 \\
\hline
\end{tabular}

The correlation analysis shows the mutual relations of the criteria characterizing students' learning. As the distribution of data did not correspond to the normal distribution, then Spearman's correlation coefficients were used (Table 3). Average to high correlation was observed among the criteria $\mathrm{C} 1, \mathrm{C} 2, \mathrm{C} 3$ and $\mathrm{C} 5$. There existed high correlation between the student's personal benefits, teacher's methods of teaching and possibilities for student's 
Dagnija CEDERE, Rita BIRZINA, Tamara PIGOZNE, Elena VASILEVSKAYA. Perceptions of today's young generation about meaningful learning of STEM

PROBLEMS

OF EDUCATION

IN THE $21^{\text {st }}$ CENTURY

Vol. 78, No. 6, 2020

collaboration and communication during learning $\left(r_{s}=.62, r_{s}=.53\right.$ and $r_{s}=.58$ respectively). These correlations confirmed that learning was personally significant for students if the teaching methods were directed to active learning.

If the young generation is more or less considered to be the "digital natives" then surprisingly the use of technologies (C4) correlates only on average with the student's personal benefits $\left(r_{s}=.33\right)$, learning methods $\left(r_{s}=.38\right)$ and communication $\left(r_{s}=.40\right)$.

\section{Table 3}

Correlations among Criteria that Describe Meaningful STEM Learning

\begin{tabular}{|c|c|c|c|c|c|c|c|}
\hline \multicolumn{2}{|c|}{ Criteria } & \multirow{2}{*}{$\begin{array}{l}\text { C1 } \\
1\end{array}$} & \multirow{2}{*}{$\begin{array}{l}\text { C2 } \\
.62^{\star *}\end{array}$} & \multirow{2}{*}{$\frac{\text { C3 }}{.53^{* *}}$} & \multirow{2}{*}{$\frac{\text { C4 }}{.33^{* *}}$} & \multirow{2}{*}{$\frac{\text { C5 }}{.37^{* *}}$} & \multirow{2}{*}{$\begin{array}{l}\text { C6 } \\
-.27^{\star \star}\end{array}$} \\
\hline $\mathrm{C} 1$ & Personal benefits & & & & & & \\
\hline $\mathrm{C} 2$ & Learning methods and strategies & & 1 & $.58^{* *}$ & $.38^{* *}$ & $.47^{\star *}$ & $-.17^{\star *}$ \\
\hline C3 & Collaboration and communication & & & 1 & $.40^{* *}$ & $.54^{* *}$ & -.10 \\
\hline C4 & Use of technologies & & & & 1 & $.49^{* *}$ & .08 \\
\hline C5 & Feedback & & & & & 1 & .04 \\
\hline C6 & Learning difficulties & & & & & & 1 \\
\hline
\end{tabular}

** Correlation is significant at .01 level (2-tailed).

The criterion C6 (learning difficulties), should be specifically noted as it has no pronounced correlation with other criteria (Table 3). One can judge that irrespective of how positively the student has assessed some teaching/learning activity it still has not caused high enough cognitive interest. This is the general trend; however, the average strong negative correlation between $\mathrm{C} 6$ and $\mathrm{C} 1\left(r_{s}=-.27\right)$ points to the purposefulness, namely, for the learning to be personally significant the student needs to make an effort.

\section{Comparison of Students'Learning per Groups of Grades}

In order to compare students' perception per groups of grades, the Kruskal-Wallis test (Table 4) was used. No significant differences among students from different grades were stated. The identified differences about some items can be mainly connected with the differences in the teaching/learning content among the groups of grades as well as different approaches used by teachers according to the age of their students. 
Dagnija CEDERE, Rita BIRZINA, Tamara PIGOZNE, Elena VASILEVSKAYA. Perceptions of today's young generation about meaningful learning of STEM

Table 4

Parameters Describing Meaningful Learning: Comparison per Grades

\begin{tabular}{|c|c|c|c|c|c|c|c|}
\hline \multirow{2}{*}{ Question } & $\begin{array}{l}\text { Grade } 10 \\
n=96\end{array}$ & $\begin{array}{l}\text { Grade } 11 \\
n=112\end{array}$ & $\begin{array}{l}\text { Grade } 12 \\
n=48\end{array}$ & $\begin{array}{l}\text { Total } \\
N=256\end{array}$ & \multirow{2}{*}{$\chi^{2}$} & \multirow{2}{*}{$d f$} & \multirow{2}{*}{$p$} \\
\hline & $M(S D)$ & $M(S D)$ & $M(S D)$ & $M(S D)$ & & & \\
\hline $\begin{array}{l}\text { 2.3. Development of skills and } \\
\text { creative abilities }\end{array}$ & $3.74(0.95)$ & $3.35(0.98)$ & $3.62(0.79)$ & $3.55(0.95)$ & 10.70 & 2 & .005 \\
\hline 3.12. Problem solving skills & $3.60(0.83)$ & $3.47(0.85)$ & $3.50(0.83)$ & $3.53(0.84)$ & 1.89 & 2 & .388 \\
\hline $\begin{array}{l}\text { 4.5. Science is not useful in } \\
\text { everyday life }\end{array}$ & $2.64(0.95)$ & $2.84(1.05)$ & $2.65(1.10)$ & $2.73(1.02)$ & 3.21 & 2 & .201 \\
\hline $\begin{array}{l}\text { 4.9. STEM is important only } \\
\text { at school }\end{array}$ & $2.81(0.99)$ & $2.74(1.05)$ & $2.75(1.08)$ & $2.77(1.03)$ & 0.93 & 2 & .954 \\
\hline $\begin{array}{l}\text { 4.13. Real life situations in } \\
\text { lessons }\end{array}$ & $3.51(0.88)$ & $3.26(1.01)$ & $3.44(0.99)$ & $3.39(0.96)$ & 3.43 & 2 & .180 \\
\hline 4.14. Interest in science & $3.46(0.95)$ & $3.05(1.09)$ & $3.17(0.83)$ & $3.23(1.01)$ & 7.29 & 2 & .026 \\
\hline 6.4. Tests are difficult & $3.41(0.85)$ & $3.38(1.09)$ & $3.46(0.97)$ & $3.40(0.98)$ & .50 & 2 & .781 \\
\hline 4.1. Prior knowledge & $3.46(0.88)$ & $3.24(0.93)$ & $3.25(0.98)$ & $3.32(0.93)$ & 2.87 & 2 & .238 \\
\hline 4.2. Experience & $3.61(0.86)$ & $3.47(0.90)$ & $3.58(0.85)$ & $3.55(0.88)$ & 1.93 & 2 & .382 \\
\hline $\begin{array}{l}\text { 4.11. My thoughts are } \\
\text { respected }\end{array}$ & $3.78(0.74)$ & $3.46(0.85)$ & $3.60(0.89)$ & $3.61(0.83)$ & 9.54 & 2 & .008 \\
\hline $\begin{array}{l}\text { 6.13. Possibility of self- } \\
\text { assessment }\end{array}$ & $3.02(1.07)$ & $2.96(1.02)$ & $3.23(0.86)$ & $3.03(1.01)$ & 2.88 & 2 & .237 \\
\hline $\begin{array}{l}\text { 6.14. Possibility to assess } \\
\text { classmates }\end{array}$ & $2.78(1.08)$ & $2.71(0.99)$ & $2.98(1.06)$ & $2.79(1.04)$ & 3.05 & 2 & .218 \\
\hline $\begin{array}{l}\text { 6.15. Possibility to receive } \\
\text { classmates' assessment }\end{array}$ & $2.71(1.13)$ & $2.67(1.01)$ & $2.83(1.04)$ & $2.71(1.06)$ & 1.12 & 2 & .571 \\
\hline
\end{tabular}

Grade 11 students have a more critical attitude to science and mathematics and lower mean values of answers in comparison with grade 10 and Grade 12 students serve as evidence to that. The attention is drawn to the fact that respondents from all grades assess relatively low $(M=2.73)$ the usefulness of the STEM knowledge and skills acquired at school in their everyday life although teachers in science lessons use the real life situations $(M=3.39)$ and science learning rather attracts than not students' interest and students in general feel good in lessons $(M=3.23)$.

It is characteristic that assessment is important for today's students - both the assessment given by the teacher and the classmate, as well as the assessment as a process, also the exchange of thoughts with classmates and the teacher is important. Students, mainly, have had a possibility to assess themselves $(M=3.03)$, there have been less possibilities to assess the classmates and to receive the classmates' assessment ( $M=2.79$ and 2.71 respectively).

\section{The Factor "Learning Difficulties" Affecting the Learning}

In order to obtain more information about students' unwillingness to make an effort and its impact on STEM learning, two groups of respondents were singled out: group A comprising students who considered that it is not difficult to learn STEM and group B - that learning is difficult. The Mann-Whitney $U$ test was used for comparing the groups, and according to it statistically significant differences between the two groups can be observed (Table 5). 
Dagnija CEDERE, Rita BIRZINA, Tamara PIGOZNE, Elena VASILEVSKAYA. Perceptions of today's young generation about meaningful learning of STEM

PROBLEMS

OF EDUCATION IN THE $21^{\text {st }}$ CENTURY Vol. 78 , No. 6, 2020

928

Table 5

Comparison of the practical importance of learning STEM

\begin{tabular}{|c|c|c|c|c|}
\hline \multirow[b]{2}{*}{ Question } & \multicolumn{2}{|l|}{$M$} & \multirow{2}{*}{$\begin{array}{l}\text { Mann- } \\
\text { Whitney } \\
U\end{array}$} & \multirow{2}{*}{$p$} \\
\hline & $\begin{array}{l}\text { Group A } \\
n=80\end{array}$ & $\begin{array}{l}\text { Group B } \\
n=51\end{array}$ & & \\
\hline 2.3. Learning develops my skills and creative abilities & 3.64 & 3.33 & 1612.0 & .030 \\
\hline 3.12. Learning develops my problem solving and thinking skills & 3.70 & 3.25 & 1553.5 & .010 \\
\hline $\begin{array}{l}\text { 4.5. Usually science topics that are acquired at school are not } \\
\text { useful for everyday life }\end{array}$ & 2.55 & 2.96 & 1563.0 & .019 \\
\hline $\begin{array}{l}\text { 4.9. I think that it is important to acquire science and mathematics } \\
\text { only at school }\end{array}$ & 2.51 & 3.08 & 1442.5 & .003 \\
\hline $\begin{array}{l}\text { 4.14. Learning science at school is interesting for me and allows } \\
\text { me feeling good }\end{array}$ & 3.46 & 2.84 & 1388.5 & .001 \\
\hline 6.4. Usually tests in science are difficult & 3.19 & 3.67 & 1420.5 & .002 \\
\hline
\end{tabular}

Group A assesses higher than group B the importance of learning science and mathematics in the development of their skills (2.3 and 3.12); however, they do not express conviction about the usefulness of the acquired skills in everyday life (4. 5 and 4.9). Group B has a more pronounced lack of learning motivation because students belonging to this group consider that STEM is needed only at school (4.9).

Another group of questions describes the teacher's action. Regarding teaching methods, the methods that are directed towards students' active participation are assessed the highest: teacher acting as a consultant $(M=3.75, S D=0.88)$, the use of experiments $(M=3.54, S D=$ $0.96)$, the use of practical, everyday life connected examples in the lessons $(M=3.89, S D=$ 0.79 ). Despite the diversity of the used methods and ensuring possibilities for students' active learning, one third (32\%) of all respondents consider that the content of lessons is of little use in everyday life ( 4.5 and 4.9). This, as if a contradiction, can be explained by the tendency characteristic to modern students for a fast, immediate result and unwillingness to go into depth in the content of learning.

\section{Discussion}

The results of the study proved that in general students of the new generation understood the role of STEM subjects and the relatively high mean values of respondents' answers served as evidence to this. The majority of students saw the link between the knowledge and skills acquired at school with the everyday life and they expressed the willingness to engage actively in the teaching/learning process at school. The identified sharp differences in students' perception testified that different students perceive STEM learning and its role in their future life rather differently.

Comparing the current study with previous studies (Cedere et al., 2018) which have concluded that students' interest in STEM domain is insufficient, it also indicates problems in this sphere. Students acknowledged the diversity of teaching methods that made the lessons interesting and exciting, yet at the same time this interest often did not go beyond the lesson and was not effective, productive (the statement "Acquiring science and mathematics is important only at school" $M=2.77, S D=1.03)$.

The modern young generation is characterized by their ability to adjust to the new conditions and to react to the fast and diverse stimuli. Differently from the three " $\mathrm{r}$ " (reading, writing, and rithmetic) characterizing the learning of the older generation, this generation is 
characterized by other three " $\mathrm{r}$ "- rigor, relevance, and real world skills (McCoog, 2008). The principles mentioned in our study clearly come into sight in the methods used by teachers yet not in the students' understanding, for they do not always perceive the importance of STEM lessons in real life.

Studies have been performed about the impact of technologies on the functioning of human brain. It has been found that the thinking of young people whose life is spent under the impact of internet and digital gadgets has changed. The fragmented information that a person receives simultaneously through several channels hinders the concentration on one task for a longer period of time (multitasking). Besides, if the information to be obtained does not require deep logical processing, its receivers gradually lose the ability to think logically and to abstract. Students' multitasking behavior can be easily seen - both in lessons and in practical classes they are regularly busy with the "on the side things", in laboratory works they desire an immediate result; they quickly forget the obtained information, they are unable to concentrate for a longer time when doing the task (Kirschner \& De Bruyckere, 2017; Rosen, 2010). These studies coincide with the results of the questionnaire (short-lived interest, unwillingness to make an effort, tests are difficult) and mark the direction of further pedagogical solutions so that the teaching/learning process could be realized according to the peculiarities of the modern new generation.

According to DiLullo (2015), the teaching/learning process should keep learners focused with the engagement in active learning, offering multitask activities (e.g., reading of the text, surfing the net and gaming tasks at the same time). This could promote concentration when learning. Also giving frequent and immediate feedback can ease the focusing on learning. As students are oriented to the use of technologies and collaboration in team, then receiving the feedback can happen through interactive social discourse. The interaction of group members, irrespective of whether it is physical or virtual always stimulates the student's motivation to learn. As the new generation is kinesthetic, experiential, hands-on learners, they prefer learning by doing not reading texts or manuals (Berk, 2009). This means that they try to connect the acquired knowledge with practical situations and the real life uses.

A very significant aspect in the STEM domain is learning that is based on the constructivist approach where great importance is laid on the skill to construe connected knowledge. The performed survey shows that a part of students have insufficiently developed critical thinking skills; besides, no differences were identified among students of different grades. New generation students have unprecedented access to information, but they need help forming a meaningful framework to understand and process this information (Moore et al., 2017).

Although students of Latvia highly approve their digital skills, the use of different technologies in learning is rather limited. Another study (Birzina \& Pigozne, 2020) confirms that there are problems with the use of the STEM specific technologies (data registration and processing systems, computer simulations of experiments). Students' answers prove that schools use social nets and on-line discussions relatively little for the teaching/learning purposes. Unfortunately, school resources not always give the possibility to use technologies to full capacity during the lessons. Students use them mainly reproductively - for searching the information, preparing the presentations, not for constructing new knowledge. This means that the assessment of the impact of technologies needed for the acquisition of science in STEM education still is provisional and allows drawing the conclusion that the teacher encounters difficulties in ensuring a meaningful use of technologies for students in the teaching/learning process. 
Dagnija CEDERE, Rita BIRZINA, Tamara PIGOZNE, Elena VASILEVSKAYA. Perceptions of today's young generation about meaningful learning of STEM

\section{PROBLEMS \\ OF EDUCATION \\ IN THE $21^{\text {st }}$ CENTURY Vol. 78, No. 6,2020 \\ 930 Conclusions and Implications}

The new generation of today is open to changes and ready for new challenges that are presented by the $21^{\text {st }}$ century with the rapid spread of information technologies. Being conscientious and purposeful, the representatives of this generation in general can assess the importance of STEM in their further advancement. However, a part of students who participated in the survey were found to be unable to delve into the essence of things and they have the desire for an immediate and easy result.

Students, in general, approve of the STEM teaching/learning process. The teacher's role has changed, the diverse teaching/learning methods have created a pleasant learning environment for students. Students are active participants of the teaching/learning process, they have a possibility to receive the feedback. The use of technologies is especially important for them and they are convinced about their digital skills. The teaching and learning organized in such a way corresponds to the peculiarities of the new generation proving that technology resources are accessible to all students for learning needs.

It is possible to observe that accepting and acknowledging the learning peculiarities characteristic to their generation, the majority of students undervalue the importance of STEM in their future life and consider that they need to learn STEM only at school.

The differences in students' perception serve as evidence that there are problems related to STEM subjects that emphasize students' diversity, differences in their thinking, views and learning styles achieving that STEM learning becomes meaningful and personally significant for every student.

\section{Limitation of the Study}

There may be some possible limitations in this study. The use of students' sample was restrictive because teachers offered filling in the questionnaire to a concrete class, thus, the population of the study included respondents with a similar profile. Teachers, mainly those working in gymnasia, volunteered to be the mediators, thus the gymnasia students prevailed in the survey. The research allows considering that the obtained results can be more interpreted as positive and the situation in all schools of Latvia could be different. Therefore, the research data describe the concrete sample.

Continuing the study, the researchers intend to compare the perceptions of students and teachers in order to gain a more comprehensive idea about the situation in teaching/learning STEM. Although it is difficult to generalize the research data of the current study and they describe more the national context, yet the characteristic trends could be important also on the international level for understanding meaningful acquisition of STEM.

\section{References}

Beers, S. (2011). 21st century skills: Preparing students for their future. Diakses Dari. http://www. yinghuaacademy. org/wp content/uploads/2014/10/21st_century_skills. pdf

Berk, R. A. (2009). Teaching strategies for the net generation. Transformative dialogues. Teaching \& Learning Journal, 3(2), 1-23.

Birzina, R., \& Cedere, D. (2017). The first-year students' perceptions of higher studies: A case of University of Latvia. In V. Dislere (Ed.), The Proceedings of the International Scientific Conference Rural Environment. Education. Personality (REEP) (Vol. 10, pp. 40-49). LLU TF. 2017. http://llufb.1lu. lv/conference/REEP/2017/Latvia-Univ-Agricult-REEP-2017_proceedings.pdf

Birzina, R., \& Pigozne, T. (2020). Technology as a tool in STEM teaching and learning. In V. Dislere (Ed.), The Proceedings of the International Scientific Conference Rural Environment. Education. Personality (REEP) (Vol. 13, pp. 219-227). LLU TF, 2020. https://lufb.llu.lv/conference/ REEP/2020/Latvia_REEP_2020_proceedings_No13_online-219-227.pdf 
Dagnija CEDERE, Rita BIRZINA, Tamara PIGOZNE, Elena VASILEVSKAYA. Perceptions of today's young generation about meaningful learning of STEM

PROBLEMS

OF EDUCATION

IN THE $21^{\text {st }}$ CENTURY

Vol. 78 , No. 6, 2020

Birzina, R., Cedere, D., \& Petersone, L. (2019). Factors influencing the first-year student's adaptation to natural science studies in higher education. Journal of Baltic Science Education, 18(3), 349-361. https://dx.doi.org/10.33225/jbse/19.18.349

Cedere, D., Birzina, R., Pigozne, T., \& Vasilevskaya, E. (2019). How to make learning in STEM meaningful for the Millennium generation. education. In V. Lamanauskas (Ed). Science and Technology Education: Current Challenges and Possible Solutions. Proceedings of the 3rd International Baltic Symposium on Science and Technology Education (BalticSTE2019) (pp. 4146). Scientia Socialis.

Cedere, D., Jurgena, I., \& Targamadze, V. (2018). Interest of Latvian and Lithuanian students in science and mathematics. Journal of Baltic Science Education, 17(1), 31-42.

Chin, C., \& Osborne, J. (2008). Students' questions: A potential resource for teaching and learning science. Studies in Science Education, 44(1), 1-39. https://doi.org/10.1080/03057260701828101

Darling-Hammond, L., Flook, L., Cook-Harvey, Ch., Barron, B., \& Osher, D. (2020). Implications for educational practice of the science of learning and development. Applied Developmental Science, 24(2), 97-140. https://dx.doi.org/10.1080/10888691.2018.1537791

DiLullo, C. (2015). Learners of a new generation. In L. K. Chan and W. Pawlina (Eds.). Teaching Anatomy: A Practical Guide (pp. 11-21). Springer.

Fadzil, H. M., Saat, R. M., Awang, K., \& Adli, D. S. H. (2019). Students' perception of learning STEMrelated subjects through scientist-teacher-student partnership (STSP). Journal of Baltic Science Education, 18(4), 537-548. https://dx.doi.org/10.33225/jbse/19.18.537

Godino, J. D., Batanero, C., Contreras, A., Estepa, A., Lacasta, E., \& Wilhelmi, M. R. (2013). Didactic engineering as design-based research in mathematics education. In B. Ubuz, C. Haser, \& M. A. Mariotti (Eds.) Proceedings of the CERME, (Vol. 8, pp. 2810-2819). Middle East Technical University. 2013. http://cerme8.metu.edu.tr/wgpapers/WG16/WG16_Godino.pdf

González, F., Morón, C., \& Novak, J. (2001). Errores conceptuales. Diagnosis, tratamiento y reflexiones. [Conceptual errors. Diagnosis, treatment and reflections]. Ediciones Eunate.

Grabinger, R. S., \& Dunlap, J. C. (1995). Rich environments for active learning: A definition. ALT-J, 3(2), 5-34.

Hofstein, A., \& Lunetta, V. N. (2004). The laboratory in science education: Foundations for the twentyfirst century. Science Education, 88(1), 28-54. https://doi.org/10.1002/sce.10106

Howe, N., \& Strauss, W. (1997). The fourth turning: What the cycles of history tell us about America's next rendezvous with destiny. Broadway.

Howell, L. P., Joad, J. P., Callahan, E., Servis, G., \& Bonham, A. C. (2009). Generational forecasting in academic medicine: A unique method of planning for success in the next two decades. Academic Medicine. 84(8), 985-993. https://doi.org/10.1097/acm.0b013e3181acf408

Kirschner, P. A., \& De Bruyckere, P. (2017). The myths of the digital native and the multitasker. Teaching and Teacher Education, 67, 135-142. https://doi.org/10.1016/j.tate.2017.06.001

Lederman, N. G., Abd-El-Khalick, F., Bell, R. L., \& Schwartz. R. S. (2002). Views of nature of science questionnaire: Toward valid and meaningful assessment of learners' conceptions of nature of science. Journal of Research in Science Teaching, 39(6), 497-521. https://doi.org/10.1002/tea.10034

Mahmoud, M. M., \& Becker, K. H., Longhurst, M. L., Dupont, R. R., Mesner, N., \& Dorward, J. (2018). Factors influencing the interest level of secondary students going into STEM fields and their parents' perceived interest in STEM (Evaluation). In ASEE Annual Conference \& Exposition. 2018.

McCoog, I. J. (2008). 21st century teaching and learning. Online submission. https://eric.ed.gov/?id=ED502607 ERIC Number: ED502607

Moore, K., Jones, C., \& Frazier, R. S. (2017). Engineering education for generation Z. American Journal of Engineering Education, 8(2), 111-125. https://doi.org/10.19030/ajee.v8i2.10067

Nel, L. (2017). Students as collaborators in creating meaningful learning experiences in technologyenhanced classrooms: An engaged scholarship approach. British Journal of Educational Technology, 48(5), 1131-1142. https://doi.org/10.1111/bjet.12549

Novak, J. D. (2002). Meaningful learning: The essential factor for conceptual change in limited or inappropriate propositional hierarchies leading to empowerment of learners. Science Education 86(4), 548 - 571. https://doi.org/10.1002/sce.10032 
Dagnija CEDERE, Rita BIRZINA, Tamara PIGOZNE, Elena VASILEVSKAYA. Perceptions of today's young generation about meaningful learning of STEM

PROBLEMS

OF EDUCATION IN THE $21^{\text {st }}$ CENTURY Vol. 78, No. 6, 2020

932

Playfoot, J., De Nicola, C., \& Di Salvadore, F. (2017). A new experiential model to innovate the STEM learning processes. In 11th International Technology, Education and Development Conference. https://pdfs.semanticscholar.org/9650/2c82a801a14c0bcbbc31b59e01c516ad3a9f.pdf

Pollard, V., Hains-Wesson, R., \& Young, K. (2018). Creative teaching in STEM. Teaching in Higher Education, 23(2), 178-193. https://doi.org/10.1080/13562517.2017.1379487

Potvin, P., \& Hasni, A. (2014). Interest, motivation and attitude towards science and technology at K-12 levels: A systematic review of 12 years of educational research. Studies in Science Education, 50(1), 85-129. https://doi.org/10.1080/03057267.2014.881626

Prensky, M. (2001). Digital natives, digital immigrants Part 1. On the Horizon, 9(5), 1-6.

Rosen, L. D. (2010). Rewired: Understanding the iGeneration and the way they learn. Palgrave Macmillan. Rubene, Z. (2018). Digital childhood: Some reflections from the point of view of philosophy of education. In: L. Daniela (Ed.), Innovations, Technologies and Researches in Education (pp. 64-77). Cambridge Scholars Publishing.

Seemiller, C., \& Grace, M. (2017). Generation Z: Educating and engaging the next generation of students. Sage Journal, 22(3), 21-26. https://doi.org/10.1002/abc.21293

Sharples, M., de Roock, R., Ferguson, R., Gaved, M., Herodotou, C., Koh, E., \& Wong, L. H. (2016). Innovating Pedagogy 2016: Open University Innovation Report 5. The Open University.

Swanzen, R. (2018). Facing the generation chasm: The parenting and teaching of generations Y and Z. International Journal of Child, Youth and Family Studies, 9(2), 125-150. https://doi.org/10.18357/ ijcyfs92201818216

Tapscott, D. (2009). Grown up digital: How the net generation is changing your world. McGraw-Hill.

Tsaparlis, G. (2020). Higher and lower-order thinking skills: The case of chemistry revisited. Journal of Baltic Science Education, 19(3), 467-483. https://dx.doi.org/10.33225/jbse/20.19.467

Received: September 28, 2020

Accepted: December 03, 2020

Cite as: Cedere, D., Birzina, R., Pigozne, T., \& Vasilevskaya, E. (2020). Perceptions of today's young generation about meaningful learning of STEM. Problems of Education in the $21^{\text {st }}$ Century, 78(6), 920-932. https://doi.org/10.33225/pec/20.78.920

\begin{tabular}{|ll|}
\hline \multirow{3}{*}{$\begin{array}{l}\text { Dagnija Cedere } \\
\text { (Corresponding author) }\end{array}$} & Dr.chem., Leading Researcher, University of Latvia, Jelgavas Str. 1, LV-1004, \\
& E-mail: dagnija.cedere@lu.Iv \\
& Website: https://www.lu.Iv \\
& ORCID: https://orcid.org/0000-0002-6654-3054 \\
\hline & Dr. paed., Leading Researcher, University of Latvia, Jelgavas Str. 1, LV-1004, \\
& Riga, Latvia. \\
Rita Birzina & E-mail: rita.birzina@lu.Iv \\
& Website: https://www.lu.Iv \\
& ORCID: https://orcid.org/0000-0002-6124-1073 \\
\hline \multirow{3}{*}{ Tamara Pigozne } & Dr. paed., Leading Researcher, University of Latvia, Imantas linija 7/1, LV- \\
& 1083, Riga, Latvia. \\
& E-mail: tamara.pigozne@lu.Iv \\
& Website: https://www.lu.Iv \\
& ORCID: https://orcid.org/0000-0002-4518-7644 \\
\hline & Dr.chem., Associate Professor, Belarusian State University, Nezavisimosti \\
& avenue 4, 220030, Minsk, Republic of Belarus. \\
& E-mail: vasileli@bsu.by \\
Website: https://bsu.by
\end{tabular}

